\title{
AKIBAT HUKUM TIDAK MEMBENTUK PERHIMPUNAN PEMILIK DAN PENGHUNI SATUAN RUMAH SUSUN
}

\author{
Arif Rahman Mahmoud ${ }^{1}$, Suhariningsih ${ }^{2}$, Imam Koeswahyono ${ }^{3}$ \\ ${ }^{1}$ Pasca Sarjana Fakultas Hukum Universitas Brawijaya \\ Email :mknub12ariefrm@gmail.com \\ ${ }^{2}$ Fakultas Hukum Universitas Brawijaya \\ Email: Shrningsihfh@gmail.com \\ ${ }^{3}$ Fakultas Hukum Universitas Brawijaya \\ Email:Imamkoeswhyn@gmail.com
}

\begin{abstract}
This article aims to determine legal consequences and remedies not filling the provisions of article 74 paragraph 1 of law number 20 year 2011 jo article 54 paragraph 1 of government regulation number 4 of 1988 concerning the association of the occupants unit of flats, using normative legal research methods, through approach to legislation, conceptual and comparison in order to obtain the views an doctrines as a basis legal arguments on legal issues studied. Based on the survey result revealed that, with no formation of associations of occupant flats units, then the resident will lose the right to enjoy a sense of comfort, easy, safe, orderly and organized the principles in the flats. According to article 107 flats legislation may be subject to adminisrative sanctions contained in article 108 of the law enactment flats in stages, ranging from a written warning to revocation of business license. Remedies that can be given the resident can do prosecution by first reporting to the local authorities for further prosecution to the developer. According article 75 paragraph 1 law flats:"development actors are required to facilitate the formation of associations occupant apartment units at the latest before the transitional period ends. In article 59 paragraph 2". The transitional period a maximum of one year since the first delivery of flats units to the owner.
\end{abstract}

Keywords: Legal Consequences, Association Occupant, Flats.

\section{ABSTRAK}

Tulisan ini bertujuan untuk mengetahui akibat hukum dan upaya hukum atas tidak dipenuhinya ketentuan Pasal 74 Ayat (1) Undang-Undang Nomor 20 Tahun 2011 Jo.Pasal 54 Ayat (1) Peraturan Pemerintah Nomor 4 Tahun 1988 Tentang Perhimpunan Penghuni Satuan Rumah Susun, dengan menggunakan metode penelitian hukum normatif, melalui pendekatan undang-undang, konseptual dan perbandingan guna memperoleh pandangan dan doktrin sebagai dasar argumentasi hukum atas isu hukum yang diteliti. Berdasarkan hasil penelitian diketahui bahwa, dengan tidak dibentuknya PPSRS, maka para penghuni akan kehilangan hak untuk menikmati rasa nyaman, mudah, aman, tertib dan teratur yang menjadi asas penyelenggaraan rumah susun. Menurut Pasal 107 UURS dapat dikenai sanksi administratif yang terdapat pada Pasal 108 UURS yang berlaku secara berjenjang, mulai dari peringatan tertulis sampai dengan pencabutan izin usaha. Upaya hukum yang dilakukan, para penghuni bisa melakukan penuntutan dengan terlebih dahulu melaporkan kepada Pemerintah Daerah setempat untuk selanjutnya dilakukan penindakan kepada pihak pengembang. Menurut Pasal 75 Ayat (1) UURS: "Pelaku pembangunan wajib memfasilitasi terbentuknya PPPSRS paling lambat sebelum masa transisi berakhir. Pasal 59 Ayat (2): Masa transisi ditetapkan paling lama 1 tahun sejak penyerahan pertama kali satuan rumah susun kepada pemilik". 
Kata Kunci: Akibat Hukum, Perhimpunan Penghuni, Rumah susun. Citation: Arif Rahman Mahmoud, dkk. "Akibat Hukum Tidak Membentuk Perhimpunan Pemilik dan Pengurus Satuan Rumah Sususn". Mulawarman Law Review 4, no. 1 (2019)

\section{PENDAHULUAN}

Semakin meningkatnya jumlah penduduk yang tinggal di perkotaan, menimbulkan konsekuensi bagi pemerintah daerah setempat utuk menyediakan tempat tinggal yang layak bagi warganya. Lahan yang tersedia semakin sempit, penyediaan tempat tinggal dilakukan dengan konsep pembangunan perumahan dalam suatu gedung bertingkat, baik horizontal maupun vertikal. Saat ini, di beberapa kota besar mulai bermunculan gedung-gedung yang dibangun dengan menggunakan konsep pemilikan bersama, baik berupa rumah susun murah sampai apartemen mewah.

Pembangunan rumah susun merupakan salah satu alternatif pemecahan masalah kebutuhan perumahan dan pemukiman terutama di daerah perkotaan yang jumlah penduduknya terus meningkat, karena pembangunan rumah susun dapat mengurangi penggunaan tanah, membuat ruang-ruang terbuka kota yang lebih lega dan dapat digunakan sebagai suatu cara untuk peremajaan kota bagi daerah yang kumuh. Pemerintah memandang perlu untuk mengembangkan konsep pembangunan perumahan yang dapat dihuni bersama di dalam suatu gedung bertingkat, dimana satuan-satuannya dapat dimiliki secara terpisah yang dibangun baik secara horizontal maupun vertikal. Pembangunan perumahan yang demikian itu sesuai dengan kebutuhan masyarakat dewasa ini, terutama masyarakat perkotaan dengan mempergunakan sistem condominium. ${ }^{1}$ Condominium menurut arti kata berasal dari bahasa latin terdiri dari dua kata, yaitu: 'co' berarti bersama-sama dan 'dominium' berarti pemilikan. Dalam perkembangan selanjutnya, condominium mempunyai arti sebagai suatu pemilikan bangunan yang terdiri atas bagian-bagian yang masing-masing merupakan suatu kesatuan yang dapat digunakan dan dihuni secara terpisah, serta dimiliki secara individual berikut bagian-bagian lain dari bangunan itu dan tanah diatas

1 Arie.S.Hutagalung, Sistem Condominium Indonesia: Implikasi dan Manfaatnya Bagi Developer/Property Owner, Makalah Program Pendidikan Ilmu Hukum FH-UI, Jakarta, hlm. 1. 
mana bangunan itu berdiri yang karena fungsinya digunakan bersama, dimiliki secara bersama-sama oleh pemilik bagian yang dimiliki secara individual tersebut di atas. ${ }^{2}$

Untuk mengantisipasi perkembangan tersebut, pemerintah telah memberlakukan Undang-Undang Nomor 16 Tahun 1985 tentang Rumah Susun.

Setelah berlaku 26 tahun, pada tahun 2011 diundangkan Undang-Undang Nomor 20 Tahun 2011 tentang Rumah Susun (UU Rusun). Di daerah perkotaan tingkat kebutuhan akan ruang sangat tinggi, konsep ruang baik hunian maupun komersial secara landed menjadi kurang efisien. Kota dengan luas tanah yang terbatas tidak dapat menjawab hal tersebut. Untuk menjawab kebutuhan tersebut di Indonesia diperkenalkan konsep hunian vertikal dalam suatu UU Rusun. Diharapkan dengan adanya aturan yang jelas dapat merangsang pembangunan rumah susun di daerah khususnya di perkotaan.

UU Rusun memperkenalkan suatu lembaga pemilikan yang baru sebagai suatu hak kebendaan, yaitu Hak Milik atas Satuan Rumah Susun (HMASRS) yang terdiri dari hak perorangan atas unit satuan rumah susun dan hak bersama atas tanah, benda dan bagian bersama yang kesemuanya merupakan satu kesatuan yang tidak terpisahkan dengan satuan-satuan yang bersangkutan. Konsep dasar yang melandasi Hak Milik Atas Satuan Rumah Susun (HMASRS) berpangkal pada teori-teori tentang pemilikan atas suatu benda/bangunan dapat dimiliki oleh seseorang, dua orang atau bahkan lebih, yang dikenal dengan istilah pemilikan bersama. Dalam pemilikan bersama atas suatu benda/bangunan pada pokoknya dikenal 2 (dua) bentuk pemilikan, yaitu, ${ }^{3}$ pemilikan bersama yang terikat (gebonden medeeigendom) dan pemilikan bersama yang bebas (vrije medeeigendom).

Dasar utama pemilikan bersama yang terikat (gebonden mede eigendom) adalah ikatan hukum yang terlebih dahulu ada diantara para pemilik benda bersamanya. Pemilikan bersama yang bebas (vrije mede eigendom), maka antara para pemilik bersama tidak terdapat ikatan hukum terlebih dahulu, selain dari hak bersama menjadi pemilik dari suatu benda. Terdapat kehendak untuk bersama-sama menjadi pemilik

\footnotetext{
${ }^{2}$ Ibid.

${ }^{3}$ Badan Pertanahan Nasional, Kebijaksanaan Pertanahan dalam Pembangunan Rumah Susun, Makalah, Jakarta, 1989, hlm. 58-60.
} 
atas suatu benda untuk digunakan bersama. Bentuk pemilikan bersama yang bebas inilah yang menurut Hukum Romawi disebut "Condominium" yang penerapannya diatur dengan undang-undang. Berdasarkan konsep tersebut, maka dalam UU Rusun dirumuskan suatu jenis pemilikan perseorangan dan pemilikan bersama dalam suatu jenis pemilikan yang baru yang disebut Hak Milik Atas Satuan Rumah Susun (HMASRS), yaitu hak pemilikan perseorangan atas satuan (unit) rumah susun, meliputi hak bersama atas bangunan, benda dan tanahnya. Pasal 3 UU Rusun menjelaskan bahwa penyelenggaraan rumah susun bertujuan untuk; (1) menjamin terwujudnya rumah susun yang layak huni dan terjangkau dalam lingkungan yang sehat, aman, harmonis, dan berkelanjutan serta menciptakan permukiman yang terpadu guna membangun ketahanan ekonomi, sosial, dan budaya; (2) meningkatkan efisiensi dan efektivitas pemanfaatan ruang dan tanah, serta menyediakan ruang terbuka hijau di kawasan perkotaan dalam menciptakan kawasan permukiman yang lengkap serta serasi dan seimbang dengan memperhatikan prinsip pembangunan berkelanjutan dan berwawasan lingkungan; (3) mengurangi luasan dan mencegah timbulnya perumahan dan permukiman kumuh; (4) mengarahkan pengembangan kawasan perkotaan yang serasi, seimbang, efisien, dan produktif; (5) memenuhi kebutuhan sosial dan ekonomi yang menunjang kehidupan penghuni dan masyarakat dengan tetap mengutamakan tujuan pemenuhan kebutuhan perumahan dan permukiman yang layak, terutama bagi MBR; (6)memberdayakan para pemangku kepentingan di bidang pembangunan rumah susun; (7)menjamin terpenuhinya kebutuhan rumah susun yang layak dan terjangkau, terutama bagi MBR dalam lingkungan yang sehat, aman, harmonis, dan berkelanjutan dalam suatu sistem tata kelola perumahan dan permukiman yang terpadu; dan (8)memberikan kepastian hukum dalam penyediaan, kepenghunian, pengelolaan, dan kepemilikan rumah susun.

Menurut Pasal 1 angka 1 UU Rusun, yang dimaksud dengan rumah susun adalah bangunan gedung bertingkat yang dibangun dalam suatu lingkungan yang terbagi dalam bagian-bagian yang distrukturkan secara fungsional, baik dalam arah horizontal maupun vertikal dan merupakan satuan-satuan yang masing-masing dapat dimiliki dan 
digunakan secara terpisah, terutama untuk tempat hunian yang dilengkapi dengan bagian bersama, benda bersama, dan tanah bersama dengan klasifikasi bahwa rusun diselenggarakan untuk memenuhi kebutuhan rumah bagi masyarakat berpenghasilan rendah, memenuhi kebutuhan khusus, dimiliki negara dan berfungsi sebagai tempat tinggal atau hunian, sarana pembinaan keluarga, serta penunjang pelaksanaan tugas pejabat dan/atau pegawai negeri, sedangkan rumah susun komersial adalah rumah susun yang diselenggarakan untuk mendapatkan keuntungan.

Secara singkat UU Rusun mengatur tata cara pembangunan, pemilikan, penghunian dan pengelolaan rumah susun. Tentang kepemilikan yang sering disebut sebagai hak milik atas satuan rumah susun (sarusun). Dijelaskan bahwa sebagai pemegang hak, seseorang berhak pula atas sebagian (proporsi) bagian bersama, benda bersama, maupun tanah bersama. Perlu diperjelas bahwa hak (kepemilikan) atas bagian bersama, benda bersama maupun tanah bersama tidak menunjuk kepada bagian atau lokasi tertentu, tetapi dalam bentuk proporsi atau prosentase kepemilikan. Hak milik atas satuan rumah susun diberikan kepada pemilik unit apartemen agar kepemilikannya dapat terlindungi di mata hukum. Dengan hak milik atas satuan rumah susun yang terdaftar dalam bentuk sertifikat hak milik atas satuan rumah susun tentunya pemilik dapat memanfaatkannya untuk keperluan lain seperti penjaminan dalam rangka memperoleh pinjaman dari Bank. Hal tersebut diharapkan semakin memperjelas masyarakat mengenai cakupan hak dari suatu hak milik atas satuan rumah susun dan tentu saja konsekuensinya. Semakin berkembangnya kota ke arah pinggiran makin membuat orang tinggal jauh dari kota dan akibatnya semakin jauhnya tempat tinggal dengan tempat kerja mengakibatkan orang habis waktu dijalan. Mengingat hal tersebut maka banyak sekarang orang membeli tempat tinggal di rumah susun atau apartemen (rumah susun komersial) agar bisa tinggal di dalam kota dan dekat dengan lokasi kantor. Adanya rumah susun atau apartemen tersebut bukan lagi hal yang baru di Indonesia, terutama di kota-kota besar seperti di kota Malang. Rumah susun atau apartemen saat ini sudah menjadi salah satu alternatif tempat tinggal yang merupakan kebutuhan dasar bagi manusia. Pasal 74 UU Rusun menjelaskan bahwa Pemilik sarusun wajib membentuk Perhimpunan Pemilik dan Penghuni Satuan Rumah 
Susun (PPPSRS) yang beranggotakan pemilik atau penghuni yang mendapat kuasa dari pemilik sarusun dan diberi kedudukan sebagai badan hukum. Masalah timbul, jika Perhimpunan Pemilik dan Penghuni Satuan Rumah Susun (PPPSRS) yang berkewajiban mengurus kepentingan para pemilik dan penghuni yang berkaitan tidak dibentuk oleh pelaku pembangunan rumah susun. Oleh karena hal itu adanya PPPSRS di rumah susun ini sangatlah diperlukan. Selain untuk dapat mengorganisir pengelolaan rumah susun agar lebih baik, adanya PPPSRS adalah untuk dapat menyeimbangkan antara hak dan kewajiban masing-masing penghuni satuan rumah susun (sarusun) agar tidak terjadi konflik dalam hal pengelolaan rumah susun tersebut.

Sampai saat ini di rumah susun komersial Apartemen Soekarno Hatta Malang masih belum terbentuk PPPSRS. Pelaku pembangunan yang diwakili oleh pengelola sementara, mengatakan PPPSRS tersebut belum terbentuk dikarenakan rumah susun komersial Apartemen Soekarno Hatta Malang masih dalam masa transisi. Padahal masa transisi sebagaimana dimaksud pada Pasal 59 Ayat (2) Undang-Undang Nomor 20 Tahun 2011 tentang Rumah Susun ditetapkan paling lama 1 (satu) tahun sejak penyerahan pertama kali satuan rumah susun (sarusun) kepada pemilik. Pada rumah susun komersial Apartemen Soekarno Hatta Malang, serah terima pertama kali unit apartemen kepada pemilik adalah pada tanggal 2 Januari 2013 yang ditandai dengan berita acara serah terima kunci. Sehingga apabila dihitung, serah terima pertama kali unit apartemen kepada pemilik sampai dengan bulan Juni 2015 adalah \pm 2 tahun 6 bulan dan Undang-undang Rumah Susun (UURS) yang baru tidak berlaku surut. Berdasarkan ketentuan tersebut, batas waktu pelaku pembangunan wajib membentuk PPPSRS di rumah susun komersial Apartemen Soekarno Hatta Malang telah berakhir sesuai dengan masa transisi yang telah ditetapkan yaitu 1 (satu) tahun sejak penyerahan pertama kali unit apartemen kepada pemilik.

Oleh karena itu dapat dikatakan bahwa pelaku pembangunan (developer) tidak dapat melaksanakan tanggungjawabnya untuk membentuk PPPSRS dalam masa transisi yang telah ditetapkan. Dalam masa transisi tersebut, pelaku pembangunan menyatakan mengalami kesulitan dalam membentuk PPPSRS. Kesulitan yang dialami oleh pelaku 
pembangunan adalah mempersiapakan syarat-syarat pembentukan PPPSRS sebagaimana yang telah dicantumkan dalam Peraturan Perundang-undangan. Tulisan ini mengkaji twntang akibat hukum yang timbul jika tidak dipenuhinya ketentuan Pasal 74 Ayat (1) Undang-Undang Nomor 20 Tahun 2011 Jo. Pasal 54 Ayat (1) Peraturan Pemerintah Nomor 4 Tahun 1988 Tentang Perhimpunan Penghuni Satuan Rumah Susun dan upaya hukum yang dilakukan atas tidak dipenuhinya ketentuan Pasal 74 Ayat (1) Undang-Undang Nomor 20 Tahun 2011 Jo. Pasal 54 Ayat (1) Peraturan Pemerintah Nomor 4 Tahun 1988 Tentang Perhimpunan Penghuni Sarusun.

\section{PEMBAHASAN}

Akibat Hukum yang Timbul jika Tidak Dipenuhinya Kewajiban membentuk Perhimpunan Penghuni Satuan Rumah Susun

Sebelum melangkah pada konsep rumah susun di Indonesia, ada baiknya perlu diketahui tentang hal-hal menyangkut hukum apartemen atau gedung bertingkat yang berlaku di beberapa negara di dunia. Pada tahun 1952 di Belanda berlaku undangundang (wet) yang memuat peraturan tentang pemeliharaan/penyediaan sesuatu yang diperlukan mengenai pemisahan hak milik dari sesuatu bangunan dalam apartemenapartemen. Undang-undang 1951 ini disebut Appartementenwet, yaitu pasal-pasal 6380 s.d 638t yang merupakan tambahan sisipan pada Ned. BW dari tahun 1838. Undang-undang ini tidak menggunakan lembaga pemisahan mendatar (tiorizontale scheiding) dari sesuatu bangunan ke dalam lotengan/bertingkat (verdiepingen/etage), melainkan bentuk baru yang disebut gebonden mede eigendom atau milik bersama (condominium) yang terikat. ${ }^{4}$

Di negara Belgia sejak tanggal 8 Juli 1942 telah berlaku undang-undang mengenai hak milik apartemen. Terjadinya undang-undang ini karena alasan-alasan yang sama seperti pada undang-undang Belanda, karena setelah perang 1914-1918, orang di Belgia, disebabkan oleh alasan-alasan ekonomis terpaksa membangun rumah-rumah flat, juga untuk penduduk yang berada. Dalam undang-undang Belgia diadakan perbedaan yang tegas antara bagian-bagian bangunan yang menjadi bagian bersama dan bagian-bagian pribadi dari pemilik-pemilik bersama dan selanjutnya oleh undang-

\footnotetext{
${ }^{4}$ Adrian Sutedi, Hukum Rumah Susun dan Apartemen, Sinar Grafika, Jakarta, 2010, hlm. 324.
} 
undang diatur mengenai pemakaian oleh tiap-tiap pemilik dari bagian-bagian bersama, dengan cara bagaimana pengurusan akan dilaksanakan, bagaimana beban-beban akan dibagi dan apa yang harus dilakukan apabila terjadi perselisihan antara pihak-pihak. ${ }^{5}$

Di Amerika Serikat masalah condominium itu diatur oleh negara-negara bagian yang bersangkutan dengan undang-undangnya (condominium laws). Pemilikan apartemen dalam bentuk condominium itu merupakan suatu absolute ownership daripada apartementnya. Di Amerika Serikat pemilikan apartemen tidak dipisahkan daripada hubungan hukum dengan tanahnya. Hak pemilikan atas apartemen itu dapat diperjualbelikan haknya kepada pihak lain dan dapat dijadikan jaminan utang. Juga disini para pemilik apartemen diwajibkan untuk bergabung dalam suatu assosiation, untuk mengatur kehidupan bersama di dalam gedung yang bersangkutan. ${ }^{6}$

Penghuni satuan rumah susun tidak dapat menghindarkan diri atau melepaskan kebutuhannya untuk menggunakan bagian bersama, benda bersama dan tanah bersama. Untuk menjamin ketertiban, gotong-royong, dan keselarasan sesuai kepribadian Indonesia dalam mengelola bagian bersama, maka dibentuk perhimpunan penghuni yang mengatur dan mengurus kepentingan bersama, karena kesemuanya merupakan kebutuhan fungsional yang saling melengkapi. ${ }^{7}$ Perhimpunan penghuni berdasarkan UU Rusun ini berkedudukan sebagai badan hukum, yang susunan organisasi, hak dan kewajibannya diatur dalam Anggaran Dasar dan Anggaran Rumah Tangga. Sebagai badan hukum, pengurus perhimpunan penghuni dapat mewakili para penghuni atau pemilik satuan rumah susun baik di dalam maupun diluar pengadilan, untuk itulah dibentuk perhimpunan penghuni. ${ }^{8}$ Perhimpunan penghuni dibentuk terutama untuk mengatur penghunian dan pengelolaan rumah susun. Kegiatannya perlu diserasikan dengan kegiatan kelembagaan RT dan RW yang bergerak di bidang kemasyarakatan. $^{9}$

Perhimpunan penghuni mempunyai tugas dan wewenang pengelolaan yang meliputi penggunaan, pemeliharan, dan perbaikan terhadap bangunan, bagian bersama, benda

\footnotetext{
${ }^{5}$ Ibid., hlm. 330.

${ }^{6}$ Ibid., hlm. 331.

${ }^{7}$ Arie.S.Hutagalung, Tebaran Pemikiran Seputar Masalah Hukum Tanah, Op.cit, hlm. 285.

${ }^{8}$ Herman Hermit, Komentar Atas Undang-undang Rumah Susun, Mandar Maju, Bandung, 2009, hlm. 103.

${ }^{9}$ Loc.cit.
} 
bersama, dan tanah bersama. Untuk pelaksanaannya, perhimpunan penghuni dapat membentuk badan pengelola apabila jumlah satuan rumah susun masih dalam batas dapat ditangani sendiri. ${ }^{10}$ Perhimpunan penghuni berimplikasi terhadap yang akan bertanggung jawab atas pengaturan dan pengelolaan satuan rumah susun selanjutnya, karena setelah semua satuan rumah susun terjual, pihak pengembang (developer) yang bersangkutan akan mengundurkan diri. Akibat hukum yang timbul jika tidak dibentuknya Perhimpunan Penghuni Satuan Rumah Susun (PPSRS), maka para penghuni akan kehilangan hak untuk menikmati rasa kenyamanan, kemudahan, keamanan, ketertiban dan keteraturan yang menjadi asas-asas penyelenggaraan rumah susun.

Asas penyelenggaraan rumah susun, pertama, asas kenyamanan, keamanan. kemudahan $^{11}$

Menurut Pasal 107 UU Rusun memberikan sanksi bagi setiap orang yang menyelenggarakan rumah susun tidak memenuhi kewajiban membentuk Perhimpunan Pemilik dan Penghuni Satuan Rumah Susun, dikenai Sanksi Administratif. Selanjutnya pada Pasal 108 dijelaskan bahwa, sanksi Administratif sebagaimana dimaksud dalam Pasal 107 berupa, Peringatan tertulis; Pembatasan kegiatan pembangunan dan/atau kegiatan usaha; Penghentian sementara pada pekerjaan pelaksanaan pembangunan; Penghentian sementara atau penghentian tetap pada pengelolaan rumah susun; Pengenaan denda administratif; Pencabutan IMB; Pencabutan sertifikat, Pencabutan SHM Sarusun atau SKBG Sarusun;Perintah pembongkaran bangunan rumah susun;Pencabutan izin usaha.

Pengenaan Sanksi Administratif tidak menghilangkan tanggung jawab pemulihan dan pidana. Ketentuan lebih lanjut mengenai Sanksi Administratif, tata cara, dan besaran denda Administratif diatur dalam Peraturan Pemerintah. Secara garis besar sanksi administratif dapat dibedakan 3 (tiga), yaitu: ${ }^{12}$

1) Sanksi Reparatif

\footnotetext{
${ }^{10}$ Ibid., hlm. 104.

${ }^{11}$ Undang-undang Nomor 28 Tahun 2002 tentang Bangunan Gedung.

${ }^{12}$ Habib Adjie, Aspek Pertanggungjawaban Notaris dalam Pembuatan Akta, Mandar Maju, Bandung, 2011, hlm. 211.
} 
Sanksi ini ditujukan untuk perbaikan atas pelanggaran tata tertib hukum. Dapat berupa penghentian perbuatan terlarang, kewajiban perubahan sikap/ tindakan sehingga tercapai keadaan semula yang ditentukan, tindakan memperbaiki sesuatu yang berlawanan dengan aturan. Contohnya paksaan untuk berbuat sesuatu untuk pemerintah dan pembayaran uang paksa yang ditentukan sebagai hukuman.

2) Sanksi Punitif

Sanksi yang bersifat menghukum, merupakan beban tambahan, sanksi hukuman tergolong dalam pembalasan, dan tindakan preventif yang menimbulkan ketakutan kepada pelanggar yang sama atau mungkin untuk pelanggar-pelanggar lainnya. Contohnya, pembayaran denda kepada pemerintah, teguran keras.

3) Sanksi Regresif

Sanksi sebagai reaksi atas suatu ketidaktaatan, dicabutnya hak atas sesuatu yang diputuskan menurut hukum, seolah-olah dikembalikan kepada keadaan hukum yang sebenarnya sebelum keputusan diambil. Contohnya, pencabutan, perubahan atau penangguhan suatu keputusan.

Sanksi-sanksi yang terdapat pada Pasal 108 Undang-undang Rumah susun tersebut berlakunya secara berjenjang, mulai dari peringatan tertulis sampai dengan pencabutan izin usaha. ${ }^{13}$ Pada Pasal 108 Undang-undang Rumah susun menempatkan peringatan tertulis pada urutan pertama dalam pemberian sanksi. Hal ini merupakan suatu peringatan kepada pemilik satuan rumah susun yang jika tidak dipenuhi atau terjadi pelanggaran ditindak lanjuti dengan sanksi teguran tertulis. Apabila sanksi seperti ini tidak dipatuhi juga oleh pemilik satuan rumah susun yang bersangkutan, maka dapat dijatuhi sanksi yang berikutnya secara berjenjang. Penempatan sanksi

13 Di dalam beberapa kepustakaan hukum administrasi dikenal beberapa jenis sanksi administratif, antara lain, (1) Eksekusi nyata yakni sanksi ini digunakan administrasi, baik dengan tidak memenuhi kewajiban yang tercantum dalam suatu ketetapan hukum-hukum administrasi maupun pada pelanggaran-pelanngaran suatu ketentuan undang-undang, berbuat tanpa izin, yang terdiri dari mengambil, menghalangi, menjalankan atau memperbaiki apa yang bertentangan dengan ketentuanketentuan dalam peraturan-peraturan yang sah, yang dibuat, disusun, dialami, dibiarkan dirusak atau diambil oleh pelaku; (2)Eksekusi langsung (parate executie), yakni, sanksi dalam penagihan uang yang berasal dari hubungan hukum-hukum administrasi;(3)Penarikan kembali suatu izin, yakni, sanksi yang diberikan pada pelanggaran peraturan atau yang berhubungan dengan ketetapan, tetapi juga pelanggaran peraturan perundang-undangan. 
berupa peringatan tertulis sebagai awal untuk menjatuhkan sanksi selanjutnya bukan termasuk sanksi administratif. Di dalam sanksi administratif berupa paksaan pemerintah, sebelum dijatuhkan sanksi harus didahului dengan teguran tertulis, hal ini dimasukkan sebagai aspek prosedur paksaan nyata.

Pelaksanaan teguran tertulis bertujuan untuk menguji ketepatan dan kecermatan antara teguran tertulis dengan pelanggaran yang dilakukan berdasarkan aturan hukum yang berlaku. Di dalam pelaksanaan teguran tertulis memberikan hak kepada mereka yang diberi teguran tertulis tersebut untuk membela diri dalam suatu upaya administrasi dalam bentuk keberatan. Dengan demikian rumusan sanksi berupa teguran tertulis tidak tepat dimasukkan sebagai suatu sanksi, tetapi hanya merupakan tahapan awal untuk menjatuhkan sanksi paksaan nyata yang untuk selanjutnya jika terbukti dapat dijatuhi sanksi yang lain.

Sanksi terhadap pemilik satuan rumah susun berupa pembatasan kegiatan pembangunan dan/atau kegiatan usaha merupakan tahap berikutnya setelah penjatuhan sanksi teguran secara tertulis. Kedudukan sanksi berupa pembatasan kegiatan pembangunan dan/atau kegiatan usaha merupakan masa menunggu pelaksanaan sanksi paksaan pemerintah.

Di dalam Risalah rancangan UU Rusun menjelaskan bahwa PPPSRS dalam kelembagan sudah jelas tata cara pembentukannya, siapa yang membentuk dikelembagaan nantinya. Di dalam hal pengendalian ini, artinya pemerintah yang wajib untuk mengendalikan atau dengan cara pengawasan. Mengawasi pembentukan PPPSRS yang dilakukan, yang dalam melakukan pembentukan ini adalah pemilik rumah susun. Pemilik rumah susun itu berkewajiban untuk membentuk PPPSRS, pembentukannya diawasi oleh pengendalian pemerintah tadi. Ada di kelembagaan, ada cara-cara pembentukan, sudah jelas pemilik sah rumah susun wajib membentuk PPPSRS dan sebagainya. Di dalam tahap pengendalian ini pemerintah wajib mengawasi pemilik rumah susun dalam membentuk PPPSRS. PPPSRS ini hanya untuk rumah susun komersial (apartemen) dan rumah susun umum, sedangkan yang lainnya bukan PPPSRS, jadi hanya untuk dua kategori rumah susun". ${ }^{14}$ Lebih lanjut dijelaskan agar

\footnotetext{
${ }^{14}$ Risalah Rancangan Undang-undang tentang Rumah Susun, hlm. 235.
} 
pemerintah lebih pada konsep, lebih agresif melakukan secepatnya pembentukan PPPSRS, sebab ini diperlukan untuk mengatur pengaturan internal, itu mutlak sekali, karena ini mengatur semua.

Menurut penulis, kesimpulan dari Risalah Rancangan Undang-undang diatas, didorong ada tindakan pemerintah untuk pembentukan perhimpunan penghuni karena undangundang mengarahkan itu. Ada peranan pemerintah yang lebih intensif, bukan hanya pengawasan tetapi juga pengendalian supaya lebih cepat proses pembentukan Perhimpunan Pemilik dan Penghuni Satuan Rumah Susun (PPPSRS) ini. Proses pembentukan PPPSRS ini sangat krusial sehingga perlu diawasi dengan cermat oleh pemerintah. Penulis mengaitkan dengan teori cita hukum seperti yang dikemukakan oleh Gustav Radbruch, bahwa hukum itu harus memenuhi berbagai karya sebagai nilai dasar dari hukum, yaitu keadilan, kegunaan, dan kepastian hukum. Nilai keadilan menunjuk pada kesamaan hak di depan hukum, nilai kegunaan menunjuk pada keadilan yaitu memajukan kebaikan dalam hidup manusia, dan nilai kepastian menunjuk hukum itu harus berisi keadilan dan norma yang mencitakan keadilan. Jika tatanan hukum dilihat dari sudut pandang positifisme, sepertinya tidak mustahil untuk mengabaikan unsur paksaan pemerintah di dalam mendefinisikan konsep hukum dan menggunakan konsep hukum menurut cara yang berbeda.

Aliran positifisme memandang suatu fakta bahwa pembuat undang-undang dapat mengundangkan perintah-perintah (norma) tanpa memandang perlu atau tidaknya untuk melekatkan suatu sanksi pidana atau perdata kepada sebuah pelanggaran. ${ }^{15}$ Menurut aliran ini, hukum adalah sesuatu yang terjadi menurut cara yang ditentukan konstitusi bagi pembentukan hukum. Konsep ini berbeda dari konsep hukum yang didefinisikan sebagai norma yang bersifat memaksa. ${ }^{16}$ Proses pembentukan hukum tidak hanya mencakup proses pembuatan undang-undang, tetapi juga prosedur otoritas pengadilan dan sanksi hukum. Namun demikian, tidak berarti bahwa segala sesuatu yang telah dibuat menurut prosedur ini adalah hukum dalam arti suatu norma hukum. Segala sesuatu yang telah dibuat menurut prosedur ini adalah norma hukum hanya jika berisikan norma untuk mengatur perbuatan manusia, dan jika mengatur

\footnotetext{
${ }^{15}$ Hans Kelsen, Teori Umum tentang Hukum dan Negara, Nusa Media, Bandung, hlm. 176.

${ }^{16}$ Loc.cit.
} 
perbuatan manusia dengan menetapkan suatu tindakan paksaan sebagai sanksi. ${ }^{17}$ Satu tahapan penting dalam proses pembentukan hukum adalah prosedur pembentukan undang-undang. Setiap undang-undang yang brlaku di Indonesia selalu ada sanksi pada akhir aturan undang-undang tersebut. Sanksi merupakan tindakan hukuman untuk memaksa orang menepati perjanjian atau ketentuan undang-undang. Pencantuman sanksi dalam berbagai aturan hukum merupakan kewajiban yang harus dicantumkan dalam setiap aturan hukum.

Aturan hukum yang bersangkutan tidak dapat ditegakkan atau tidak akan dipatuhi apabila pada bagian akhir tidak mencantumkan sanksi. Tidak ada gunanya memberlakukan kaidah-kaidah jika tidak dapat dipaksakan melalui sanksi dan menegakkan kaidah dimaksud secara prosedural (hukum acara). Hakekat sanksi sebagai suatu paksaan berdasarkan hukum, juga untuk memberikan penyadaran kepada pihak yang melanggarnya, bahwa suatu tindakan yang dilakukannya telah tidak sesuai dengan aturan hukum yang berlaku, dan untuk mengembalikan yang bersangkutan agar bertindak sesuai dengan aturan hukum yang berlaku, juga untuk menjaga keseimbangan berjalannya suatu aturan.

Sanksi merupakan alat pemaksa, selain hukuman, juga untuk mentaati ketetapan yang ditentukan dalam peraturan atau perjanjian. Sanksi juga diartikan sebagai alat pemaksa sebagai hukuman jika tidak taat kepada perjanjian. Menurut Philipus M.Hadjon, sanksi merupakan alat kekuasaan yang bersifat hukum publik yang digunakan oleh penguasa sebagai reaksi terhadap ketidakpatuhan pada norma hukum administrasi. Dengan demikian unsur-unsur sanksi, yaitu: ${ }^{18}$ (a) sebagai alat kekuasaan; (b) bersifat hukum publik; (c) digunakan oleh penguasa; (d) sebagai reaksi terhadap ketidakpatuhan. Sanksi ini selalu ada pada aturan-aturan hukum yang dikualifikasikan sebagai aturan hukum yang bersifat memaksa. Ketidaktaatan atau pelanggaran terhadap suatu kewajiban yang tercantum dalam aturan hukum mengakibatkan terjadinya ketidakaturan yang sebenarnya tidak diinginkan oleh aturan hukum yang bersangkutan. Hal ini sesuai dengan fungsi sanksi yang dipakai untuk penegakkan hukum terhadap ketentuan-ketentuan yang biasanya berisi suatu larangan atau yang

\footnotetext{
${ }^{17}$ Ibid., hlm. 178.

${ }^{18}$ Philipus M.Hadjon, Penegakkan Hukum Administrasi, Yuridika, Surabaya, 1996, hlm. 1.
} 
mewajibkan. ${ }^{19}$ Dengan demikian sanksi pada hakikatnya merupakan instrumen yuridis yang biasanya diberikan apabila kewajiban-kewajiban atau larangan-larangan yang ada dalam ketentuan hukum telah dilanggar. Dan dibalik pintu ketentuan perintah dan larangan (geen verboden) tersedia sanksi untuk memaksa kepatuhan. Undang-Undang Jabatan Notaris berisikan ketentuan yang bersifat memaksa atau merupakan suatu aturan hukum yang imperatif untuk ditegakkan terhadap Notaris yang telah melanggar dalam menjalankan tugas jabatannya. ${ }^{20}$

Adanya lembaga kemasyarakatan yang cukup unik dalam lingkungan rumah susun, yaitu perhimpunan penghuni memperlihatkan bahwa Pemerintah masih merasa harus campur tangan melalui pengaturan pranata sosial tersebut, yang dianggapnya tidak kalah penting dari pengaturan persyaratan teknis bangunan gedung. Hal ini dapat dipahami bukan hanya dalam perspektif pentingnya kebersamaan dalam lingkungan hunian model vertikal mengingat adanya bagian bersama, benda bersama dan tanah bersama, melainkan juga demi keselamatan dan keamanan lingkungan hunian yang batas-batas fisiknya tidak lain adalah serba beton yang sesungguhnya bukan hanya mempunyai life time akan tetapi juga bisa rentan terhadap kekuatan fisik eksogen seperti gempa dan petir yang berimplikasikan pada keharusan untuk merawat dan memonitor sistem bangunan gedung rumah susun secara bersama dan profesional (mempunyai kompetensi teknik bangunan). ${ }^{21}$ Dengan demikian bahwa kelayakan hunian sebuah bangunan gedung bukan tanpa batas usia material bangunan, dan karenanya keberlanjutan fungsi huniannya akan menjadi lebih ditentukan oleh keputusan-keputusan bersama penghuni atau pun pemilik satuan-satuan rumah susun melalui organisasi bernama perhimpunan penghuni.

\footnotetext{
${ }^{19}$ Philipus M.Hadjon, Pemerintahan Menurut Hukum, Yuridika, Surabaya, 1992, hlm. 6.

${ }^{20}$ Ibid., hlm. 5.

${ }^{21}$ Herman Hermit, Op.cit, hlm. 106.
} 
Upaya Hukum yang Dilakukan atas Tidak Dipenuhinya Ketentuan Pasal 74 Ayat (1) Undang-undang Nomor 20 Tahun 2011 Jo. Pasal 54 Ayat (1) Peraturan Pemerintah Nomor 4 Tahun 1988 tentang Perhimpunan Penghuni Satuan Rumah Susun

Keanggotaan perhimpunan penghuni didasarkan kepada realita penghunian artinya yang dapat menjadi anggota perhimpunan adalah mereka yang benar-benar menghuni atau menempati satuan rumah susun, baik atas dasar pemilikan maupun hubungan hukum lainnya, seperti sewa-menyewa, sewa beli dan sebagainya. Apabila pemilik belum menghuni, memakai atau memanfaatkan satuan rumah susun yang bersangkutan, maka pemilik harus menjadi anggota perhimpunan penghuni, sedangkan apabila penyelenggara pembangunan belum dapat menjual seluruh satuan rumah susun, maka penyelenggara pembangunan harus bertindak sebagai anggota pehimpunan penghuni. ${ }^{22}$ Menurut Arie.S Hutagalung: ${ }^{23}$ ada dua kemungkinan dalam pembentukan lembaga ini (perhimpunan penghuni). Kemungkinan pertama terkait dengan perhimpunan penghuni. Sedangkan kemungkinan kedua adalah adanya pihak ketiga yang merupakan badan hukum profesional. Di antara dua pilihan ini mempunyai implikasi yang berlainan satu dengan yang lainnya.

Apabila badan pengelola satuan rumah susun ditunjuk oleh perhimpunan penghuni, maka yang penting untuk diperhatikan adalah sebagai berikut: ${ }^{24}$

1) Badan pengelola ini harus berbentuk badan hukum atau recht person yang melaksanakan tugas berdasarkan suatu perjanjian formal, dengan perhimpunan penghuni.

2) Badan pengelola yang dibentuk oleh perhimpunan penghuni ini harus profesional. Artinya, suatu badan hukum yang benar-benar mempunyai kemampuan untuk mengelola suatu bangunan bertingkat.

Kewajiban badan pengelola rumah susun pada hakikatnya telah ditentukan dalam Pasal 66 Peraturan Pemerintah Nomor 4 Tahun 1988 tentang Rumah Susun yang esensinya mencakup hal-hal sebagai berikut:

\footnotetext{
${ }^{22}$ Andi Hamzah dkk, Dasar-dasar Hukum Perumahan, Rineka Cipta, Jakarta, 2006, hlm. 44.

${ }^{23}$ Imam Koeswahyono, Hukum Rumah Susun (Suatu Bekal Pengantar Pemahaman), Bayumedia Publishing, Malang, 2004, hlm. 88 .

${ }^{24}$ Loc.cit.
} 
1) Melaksanakan pemeriksaan, pemeliharaan kebersihan rumah susun dan lingkunganya pada bangunan bersama, benda bersama dan tanah bersama.

2) Mengawasi ketertiban dan keamanan penghuni serta penggunaan bangunan bersama, benda bersama dan tanah bersama sesuai dengan peruntukannya.

3) Secara berkala memberikan laporan kepada perhimpunan penghuni disertai permasalahan dan usulan pemecahannya.

Adapun yang menjadi hak dari badan pengelola rumah susun adalah berikut:

1) Menerima pembayaran iuran pengelolaan atau service charge dari masingmasing penghuni rumah susun.

2) Menerima pembayaran lumpsum dari penghuni rumah susun.

Seperti telah dijelaskan diatas, dalam mengelola rumah susun dan lingkungannya, perhimpunan penghuni dapat menunjuk atau membentuk Badan pengelola rumah susun. Badan pengelola ini harus dilengkapi dengan unit organisasi, personil dan peralatan yang mampu untuk mengelola rumah susun.

Diperlukan penegasan dalam hal keanggotaan perhimpunan penghuni. Menurut Pasal 55 ayat (1) Peraturan Pemerintah Nomor 4 Tahun 1988 bahwa yang menjadi anggota perhimpunan penghuni adalah subyek hukum yang memiliki, atau memakai, atau menyewa, atau menyewa beli atau yang memanfaatkan satuan rumah susun yang bersangkutan yang berkedudukan sebagai penghuni. Berdasarkan ketentuan tersebut, maka penghuni satuan rumah susun belum tentu pemilik satuan rumah susun itu sendiri, sehingga kewajiban dari pemilik satuan rumah susun membentuk dan menjadi anggota perhimpunan penghuni, jika pemilik satuan rumah susun sekaligus berkedudukan sebagai penghuni. Apabila pemilik satuan rumah susun itu menyewakan satuan rumah susunnya kepada pihak lain, maka yang menjadi anggota perhimpunan penghuni adalah si penyewa dari satuan rumah susun itu dan bukan pemiliknya. ${ }^{25}$ Upaya hukum yang dilakukan jika tidak dibentuknya Perhimpunan Penghuni Satuan Rumah Susun (PPSRS), maka para penghuni bisa melakukan penuntutan dengan

${ }^{25}$ Arie. S. Hutagalung, Kondominium dan Permasalahannya (edisi revisi), Badan Penerbit FHUI, Jakarta, 2007, hlm. 64. 
terlebih dahulu melaporkan kepada Pemerintah Daerah setempat untuk selanjutnya dilakukan penindakan kepada pihak pengembang. Perhimpunan penghuni ini mutlak keberadaannya. Menurut Pasal 75 Ayat (1) Undang-Undang Nomor 20 Tahun 2011 tentang Rumah Susun: "Pelaku pembangunan wajib memfasilitasi terbentuknya PPPSRS paling lambat sebelum masa transisi berakhir". ${ }^{26}$

Pada masa transisi kedudukan pelaku pembangunan berubah statusnya menjadi pengelola sementara atas satuan rumah susun. Sehubungan dengan hal tersebut, maka muncul sebuah pembahasan mengenai tanggung jawab yang harus dilakukan pelaku pembangunan dalam hal memfasilitasi pembentukan PPPSRS yang beranggotakan pemilik atau penghuni satuan rumah susun (sarusun) sesuai dengan peraturan yang telah ditetapkan, yaitu pada Pasal 75 Ayat (1)UU Rusun. Pada Pasal 75 Ayat (1) ini merupakan persyaratan mutlak yang harus dipenuhi. Mengingat dalam pasal tersebut ditekankan kata "wajib" yang berarti adanya suatu keharusan. Pada Pasal 59 Ayat (1)UU Rusun menyatakan bahwa pelaku pembangunan yang membangun rumah susun umum milik dan rumah susun komersial dalam masa transisi sebelum terbentuknya PPPSRS wajib mengelola rumah susun". Berdasarkan Pasal 59 Ayat (1), maka pelaku pembangunan bertindak sebagai pengelola sementara dalam masa transisi sebelum PPPRS terbentuk. Tanpa melihat ketentuan Pasal 59 Ayat (2), masa transisi yang dimaksud hanya 1 (satu) tahun sejak penyerahan pertama kali satuan rumah susun (sarusun) kepada pemilik, pelaku pembangunan terus menjadi pengelola sementara.

Penulis berpendapat bahwa pengelolaan satuan rumah susun (sarusun) itu mempunyai nilai ekonomis jangka panjang, sehingga pelaku pembangunan (developer) yang bertindak sebagai pengelola sementara dari rumah susun terus berupaya mencari keuntungan dari pengelolaan rumah susun tersebut. Beberapa masalah dalam pengelolaan rumah susun sering terjadi, mulai dari penentuan besaran service charge, hubungan antara badan pengelola sementara atau pelaku pembangunan dengan para penghuni, hingga interaksi antar sesama penghuni rumah susun tersebut.

\footnotetext{
${ }^{26}$ Pada Pasal 59 Ayat (2) dijelaskan bahwa masa transisi ditetapkan paling lama 1 (satu) tahun sejak penyerahan pertama kali satuan rumah susun (sarusun) kepada pemilik.
} 
Permasalahan dalam pengelolaan satuan rumah susun terkait dengan Perhimpunan Penghuni Rumah Susun (PPRS). PPRS yang didominasi para karyawan pelaku pembangunan seringkali menimbulkan ketidakpercayaan bagi sebagian penghuni rumah susun yang bersangkutan. Para penghuni bisa saja dijadikan sumber pendapatan dengan modus penerapan iuran yang tinggi atau tidak wajar, ditambah lagi tidak adanya transparansi tentang penggunaan biaya iuran tersebut kepada para penghuni rumah susun. Ketentuan mengenai pengelola rumah susun sudah ditegaskan dalam Pasal 74 UU Rusun yang memberi perintah bahwa pemilik sarusun wajib membentuk PPPSRS.

Pengelolaan terhadap rumah susun dan lingkungannya dapat dilaksanakan oleh suatu badan pengelola yang ditunjuk atau dibentuk oleh perhimpunan penghuni. Pengelolaan rumah susun ini meliputi kegiatan-kegiatan operasional yang berupa pemeliharaan, perbaikan dan pembangunan prasarana lingkungan serta fasilitas sosial. Pembiayaan pengelolaan bagian bersama dan tanah bersama dibebankan kepada penghuni atau pemilik secara proporsional melalui perhimpunan penghuni. ${ }^{27}$ Dari segi kepastian hukum, penghuni satuan rumah susun dengan sendirinya akan terlibat di dalam masalah penggunaan bagian bersama, benda bersama dan tanah bersama yang ada pada rumah susun yang bersangkutan. Untuk itulah maka undang-undang menetapkan bahwa para penghuni harus menghimpun diri dalam Perhimpunan Penghuni yang akan mengurus kepentingan bersama tersebut, karena undang-undang perhimpunan penghuni tersebut dinyatakan sebagai Badan Hukum. Hukum sebagai sistem norma yang menekankan aspek seharusnya atau das solen dengan memprediksi terlebih dahulu tidak bisa diturunkan dari kenyataan, norma hukum selalu diciptakan melalui kehendak, sebuah tindakan hanya dapat menciptakan hukum, dan hukum yang diciptakan harus sesuai dengan norma hukum yang lebih tinggi.

\footnotetext{
${ }^{27}$ Adrian Sutedi, Op.cit., hlm. 229.
} 


\section{SIMPULAN}

Akibat hukum yang timbul jika tidak dipenuhinya ketentuan Pasal 74 Ayat (1) UndangUndang Nomor 20 Tahun 2011 Jo. Pasal 54 Ayat (1) Peraturan Pemerintah Nomor 4 Tahun 1988 Tentang Perhimpunan Penghuni Satuan Rumah Susun, dengan tidak dibentuknya PPSRS, maka para penghuni akan kehilangan hak untuk menikmati rasa kenyamanan, kemudahan, keamanan, ketertiban dan keteraturan yang menjadi asas penyelenggaraan rumah susun. Menurut Pasal 107 UURS dapat dikenai sanksi administratif yang terdapat pada Pasal 108 UURS berlakunya secara berjenjang, mulai dari peringatan tertulis sampai dengan pencabutan izin usaha. Peranan pemerintah yang lebih intensif, bukan hanya pengawasan tapi juga pengendalian agar lebih cepat proses pembentukan perhimpunan penghuni.

Upaya hukum yang dilakukan atas tidak dipenuhinya ketentuan kewajiban pembentukan Perhimpunan Penghuni Satuan Rumah Susun, maka para penghuni bisa melakukan penuntutan dengan terlebih dahulu melaporkan kepada Pemerintah Daerah setempat untuk selanjutnya dilakukan penindakan kepada pihak pengembang.

\section{DAFTAR PUSTAKA}

Adjie Habib, Aspek Pertanggungjawaban Notaris dalam Pembuatan Akta. Bandung: Mandar Maju, 2011.

Adrian Sutedi, Hukum Rumah Susun dan Apartemen, Jakarta: Sinar Grafika, 2010.

Andi Hamzah dkk, Dasar-Dasar Hukum Perumahan, Jakarta:Rineka Cipta, 2006.

Arie Hutagalung, Sistem Condominium Indonesia: Implikasi dan Manfaatnya Bagi Developer/Property Owner, Jakarta:Makalah Program Pendidikan IImu Hukum FH-UI, Jakarta. FHUI, 2007.

2005.

, Tebaran Pemikiran Seputar Masalah Hukum Tanah, Jakarta:LPHI,

Badan Pertanahan Nasional, Kebijaksanaan Pertanahan dalam Pembangunan Rumah Susun, Jakarta: Makalah, 1989.

Hermit Herman, Komentar Atas Undang-Undang Rumah Susun, Bandung: Mandar Maju, 2009. 
P-ISSN: 2527-3485, E-ISSN: 2527-3477

Hadjon M. Philipus., Pemerintahan Menurut Hukum, Surabaya: Yuridika, 1992. , Penegakkan Hukum Administrasi, Surabaya: Yuridika, 1996.

Imama Koeswahyu, Hukum Rumah Susun (Suatu Bekal Pengantar Pemahaman), Malang: Bayumedia Publishing, 2004. 